\title{
Value choices in life cycle impact assessment of stressors causing human health damage
}

An M. De Schryver*, Rosalie van Zelm, Sebastien Humbert, Stephan Pfister, Thomas E. McKone, Mark A.J. Huijbregts

*E-mail: an.schryver@gmail.com

\section{SUPPORTING INFORMATION}

This is an earlier version of the following article: De Schryver A.M., Van Zelm R., Humbert S., Pfister S., Huijbregts M.A.J. 2011. Value choices in life cycle impact assessment of stressors causing human health damage. Journal of Industrial Ecology 15(5): 796-815, , which was published in final form at http://onlinelibrary.wiley.com/doi/10.1111/j.15309290.2011.00371.x/abstract.

\section{SUMMARY}

This supporting information provides a detailed description of and argumentation on the choices and equations that were used to make the model presented in the main text. It contains four tables, which describe (i) the suggested combination of value choices for each human health impact category, (ii) the disability-adjusted life year per incidence case calculated for the different impact categories, (iv) the disability-adjusted life year per degree Celsius increase for climate change, and (v) the percentage damage contribution for substances that contribute to the global damage emissions and water consumption. 


\section{Supporting Information S1}

\section{Methodology \\ Value choices}

Table S1-1. Suggested combination of value choices on the level of concern (C) and the level of uncertainty (U), applied to the three perspectives for human health. Choices on the level of fate factor, exposure factor, effect factor and damage factor are separated for each impact category (IC).

\begin{tabular}{|c|c|c|c|c|c|c|}
\hline IC & Step & Value choices & Individualist & Hierarchist & Egalitarian & $\begin{array}{l}\text { Not } \\
\text { e }\end{array}$ \\
\hline \multirow{5}{*}{ 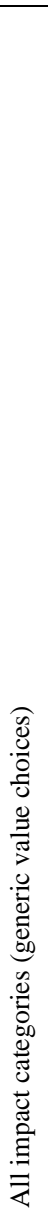 } & \multirow[b]{2}{*}{ 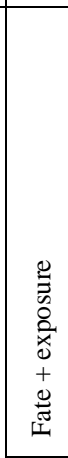 } & $\begin{array}{l}\text { The change in concentration due to a change in emission is } \\
\text { substance lifetime specific and depends on the time horizon after } \\
\text { which the change in concentration is measured (Huijbregts et al., } \\
\text { 2005). As temporal vision on life and society is perspective } \\
\text { dependent, different timeframes are applied for each perspective } \\
\text { (Jager et al., 1997, De Schryver et al., 2009). }\end{array}$ & 20years & 100years & Infinite & $\mathrm{C}$ \\
\hline & & $\begin{array}{l}\text { Future projections on demographical developments, population } \\
\text { displacements, changes in GDP, years of schooling and } \\
\text { technology changes will alter the sensitivity, size and age } \\
\text { composition of the population and thus influence the number of } \\
\text { cases (incidence) per emitted substance (Mathers and Loncar, } \\
\text { 2006). Future optimistic, baseline and pessimistic scenarios } \\
\text { (IPCC, 2000, Murray and Lopez, 1997), can be linked to the } \\
\text { individualist, hierarchist and egalitarian perspectives. }\end{array}$ & $\begin{array}{l}\text { Optimistic } \\
\text { development }\end{array}$ & $\begin{array}{l}\text { Baseline } \\
\text { development }\end{array}$ & $\begin{array}{l}\text { Pessimistic } \\
\text { development }\end{array}$ & $\mathrm{U}^{\mathrm{a}}$ \\
\hline & \multirow[b]{3}{*}{ 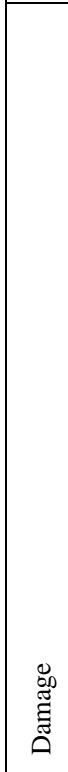 } & $\begin{array}{l}\text { Discounting years of life lost in the future is perspective } \\
\text { dependent. Janssen et al. (1995) propose a } 0 \% \text { time discount rate } \\
\text { for the egalitarian perspective, a } 2 \% \text { discount for the hierarchist } \\
\text { perspective and a 5\% discount for the individualist perspective. } \\
\text { We follow this vision, except for the hierarchist perspective } \\
\text { where a } 3 \% \text { discount rate is chosen, as this is used as default } \\
\text { scenario by the World Health Organization (Murray and Lopez, } \\
\text { 1996c, WHO, 2008b). }\end{array}$ & $5 \%$ & $3 \%$ & $0 \%$ & $\mathrm{C}$ \\
\hline & & $\begin{array}{l}\text { Age weighting allocates a higher importance to a year of life at } \\
\text { young age than at old age or infants (Murray and Lopez, 1996c). } \\
\text { A higher value for economically more relevant subpopulations } \\
\text { corresponds with the individualist perspective, while the group } \\
\text { bounded hierarchists and egalitarian perspectives do not } \\
\text { differentiate between individuals with different ages (Gold et al., } \\
\text { 1996, Murray and Lopez, 1996c). }\end{array}$ & Yes & No & No & $\mathrm{C}$ \\
\hline & & $\begin{array}{l}\text { For the impact category particulate matter and ozone formation, } \\
\text { part of the damage (chronic diseases) takes place in the future. } \\
\text { For other impact categories, the lifetime of the substances is } \\
\text { important regarding effects that take place in the future. Future } \\
\text { effects are affected by the level of manageability/ adaptation. } \\
\text { Better health care system, education and legislation can reduce } \\
\text { the disability-adjusted life years (DALYs) per case in the future } \\
\text { (Hofstetter, 1998). The type of management is perspective } \\
\text { dependent (Thompson et al., 1990, van Asselt et al., 1996). }\end{array}$ & $\begin{array}{l}\text { Adaptive } \\
\text { management } \\
\text { style }\end{array}$ & $\begin{array}{l}\text { Controlling } \\
\text { management } \\
\text { style }\end{array}$ & $\begin{array}{l}\text { Comprehens } \\
\text { ive } \\
\text { management } \\
\text { style }\end{array}$ & $\mathrm{U}^{\mathrm{a}}$ \\
\hline \multirow[b]{2}{*}{ 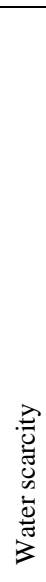 } & 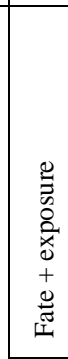 & $\begin{array}{l}\text { Water availability depends on variability in precipitation. } \\
\text { Variability in precipitation gives a certain water stress that } \\
\text { depends on the water storage capacities. The correction factor } \\
\text { (Corr) for water stress due to variability in precipitation (VF) } \\
\text { depends on the level of flow regulation by providing sufficient } \\
\text { storage structures(Pfister et al., 2009). According to van Asselt } \\
\text { and Rotmans (1996), the individualist perspective coincides with } \\
\text { an adaptive management style. Therefore a lower variability } \\
\text { factor is suggested. For the hierarchist and egalitarian } \\
\text { perspectives the original variability factor, as presented by } \\
\text { Pfister et al.(2009), is maintained. }\end{array}$ & $\begin{array}{l}\text { Strong } \\
\text { regulated } \\
\text { flows: Corr=1 } \\
\text { Weak } \\
\text { regulated } \\
\text { flows: } \\
\text { Corr }=\sqrt{ } \mathrm{VF}\end{array}$ & $\begin{array}{l}\text { Strong } \\
\text { regulated } \\
\text { flows: } \\
\text { Corr }=\sqrt{ } \mathrm{VF} \\
\text { Weak } \\
\text { regulated } \\
\text { flows: } \\
\text { Corr=VF }\end{array}$ & $\begin{array}{l}\text { Strong } \\
\text { regulated } \\
\text { flows: } \\
\text { Corr }=\sqrt{ } \mathrm{VF} \\
\text { Weak } \\
\text { regulated } \\
\text { flows: } \\
\text { Corr=VF }\end{array}$ & $\mathrm{U}$ \\
\hline & 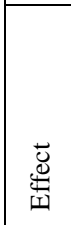 & $\begin{array}{l}\text { A food water requirement of } 1350 \mathrm{~m}^{3} \text { per capita per year is the } \\
\text { minimum direct human dietary requirement and is used to derive } \\
\text { malnutrition cases per amount of water deprivation (Pfister et } \\
\text { al., 2009). Good management can drop the food water } \\
\text { requirement to } 1000 \mathrm{~m}^{3} \text { per person by } 2050 \text { (Rockstrom } 2006 \text { ). } \\
\text { i.e., } 74 \% \text { of the water requirement and consequently of the } \\
\text { expected health effect. This results in } 1 \text { case per } 1823 \mathrm{~m}^{3} \text { per year }\end{array}$ & $\begin{array}{l}0.74 \text { case per } \\
1350 \mathrm{~m}^{3} / \mathrm{yr} \\
= \\
1 \text { case per } \\
1823 \mathrm{~m}^{3} / \mathrm{yr}\end{array}$ & $\begin{array}{l}1 \text { case per } \\
1350 \mathrm{~m}^{3} / \mathrm{yr}\end{array}$ & $\begin{array}{l}1 \text { case per } \\
1350 \mathrm{~m}^{3} / \mathrm{yr}\end{array}$ & $\mathrm{U}$ \\
\hline
\end{tabular}




\begin{tabular}{|c|c|c|c|c|c|c|}
\hline & & $\begin{array}{l}\text { water deprived. A water requirement of } 1350 \mathrm{~m}^{3} \text { per year is } \\
\text { applied for the hierarchist and egalitarian perspectives. A good } \\
\text { management level, and thus } 1 \text { case per } 1823 \mathrm{~m}^{3} \text { per year is } \\
\text { assumed for the individualist perspective. }\end{array}$ & & & & \\
\hline & 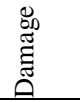 & $\begin{array}{l}\text { Generic value choices only (presented for all ICs at start of the } \\
\text { table). }\end{array}$ & I & I & I & I \\
\hline \multirow{4}{*}{ 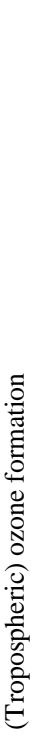 } & 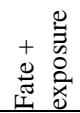 & $\begin{array}{l}\text { Generic value choices only (presented for all ICs at start of the } \\
\text { table). }\end{array}$ & I & I & l & I \\
\hline & & $\begin{array}{l}\text { The effect factor is calculated for an average } 24 \mathrm{~h} \text { concentration } \\
\text { and the daily highest } 8 \mathrm{~h} \text { concentration. The average } 24 \mathrm{~h} \\
\text { concentration gives a negative total damage from } \mathrm{NO}_{\mathrm{x}} \text { due to } \\
\text { more ozone degradation than formation (Van Zelm et al., 2008). } \\
\text { Including or excluding the positive effects of ozone degradation } \\
\text { (applying the } 24 \mathrm{~h} \text { or } 8 \mathrm{~h} \text { scenario) is considered to be a value } \\
\text { choice on the level of concern. Positive effects (24h scenario) } \\
\text { are only included for the individualist perspective as they } \\
\text { consider nature as being stable with assured recovery } \\
\text { (Hofstetter, 1998). For the egalitarian and hierarchist } \\
\text { perspectives we apply the } 8 \text { highest hours of concentration to } \\
\text { calculate the effects. }\end{array}$ & 24 hours & 8 hours & 8 hours & $\mathrm{C}$ \\
\hline & 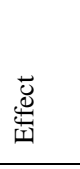 & $\begin{array}{l}\text { The amount of knowledge about ozone-related morbidity is } \\
\text { limited (Vonk and Schouten, 2002, Anderson et al., 2004). } \\
\text { Therefore, morbidity from asthma, minor restricted activity } \\
\text { days, respiratory hospital admissions and symptom days is only } \\
\text { included in the egalitarian perspective (Hofstetter, 1998). }\end{array}$ & Excluded & Excluded & Included & $\mathrm{U}$ \\
\hline & 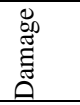 & $\begin{array}{l}\text { Generic value choices only (presented for all ICs at start of the } \\
\text { table). }\end{array}$ & I & I & I & I \\
\hline \multirow{4}{*}{ 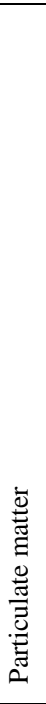 } & 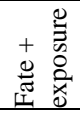 & $\begin{array}{l}\text { Generic value choices only (presented for all ICs at start of the } \\
\text { table). }\end{array}$ & I & I & I & I \\
\hline & & $\begin{array}{l}\text { Evidence for effects from primary } \mathrm{PM}_{10} \text { is available (Pope et al., } \\
\text { 2009) and therefore included for all perspectives. Evidence } \\
\text { concerning human health risks at ambient concentrations of } \\
\text { secondary PM from } \mathrm{SO}_{2}, \mathrm{NO}_{x} \text { and } \mathrm{NH}_{3} \text { is available (Reiss et al., } \\
\text { 2007, USEPA, 2009). However, the level of effect is still being } \\
\text { debated (Hofstetter, 1998, Torfs et al., 2007) and therefore } \\
\text { excluded for the individualist perspective. Reiss et al. (2007) } \\
\text { shows that there are more studies indicating health effects from } \\
\text { secondary PM from } \mathrm{SO}_{2} \text { than from } \mathrm{NO}_{x} \text { or } \mathrm{NH}_{3} \text {. Therefore, in } \\
\text { the hierarchist perspective, we decided to include effects from } \\
\text { secondary PM from } \mathrm{SO}_{2} \text { only. }\end{array}$ & Primary $\mathrm{PM}_{10}$ & $\begin{array}{l}\text { Primary } \\
\mathrm{PM}_{10}+ \\
\text { secondary } \\
\mathrm{PM} \text { from } \\
\mathrm{SO}_{2}\end{array}$ & $\begin{array}{l}\text { Primary } \\
\mathrm{PM}_{10}+ \\
\text { secondary } \\
\mathrm{PM} \text { from } \\
\mathrm{SO}_{2}, \mathrm{NO}_{x} \\
\text { and } \mathrm{NH}_{3}\end{array}$ & $\mathrm{U}$ \\
\hline & 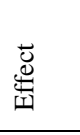 & $\begin{array}{l}\text { The amount of knowledge about asthma, chronic obstructive } \\
\text { pulmonary disease, croup in preschool children and ischaemic } \\
\text { heart disease is limited. Therefore, these effects are only } \\
\text { included in the egalitarian perspective (Hofstetter, 1998). }\end{array}$ & Excluded & Excluded & Included & $U$ \\
\hline & 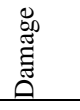 & $\begin{array}{l}\text { Generic value choices only (presented for all ICs at start of the } \\
\text { table). }\end{array}$ & I & I & I & 1 \\
\hline \multirow[b]{3}{*}{ 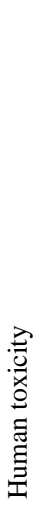 } & \multirow[b]{2}{*}{ 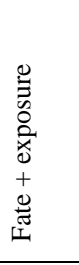 } & $\begin{array}{l}\text { Generic value choices only (presented for all ICs at start of the } \\
\text { table). }\end{array}$ & I & I & l & l \\
\hline & & $\begin{array}{l}\text { The bioconcentration factor for metals is less than proportional } \\
\text { with the environmental concentration (Hendriks et al., 2001). } \\
\text { Therefore, oral intake of metals via food (bioaccumulation) is } \\
\text { excluded for the individualist perspective, but included for the } \\
\text { hierarchist and egalitarian perspectives. }\end{array}$ & $\begin{array}{l}\text { Intake through } \\
\text { drinking water, } \\
\text { air }\end{array}$ & $\begin{array}{l}\text { Intake } \\
\text { through all } \\
\text { routes }\end{array}$ & $\begin{array}{l}\text { Intake } \\
\text { through all } \\
\text { routes }\end{array}$ & $\mathrm{U}$ \\
\hline & 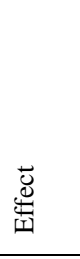 & $\begin{array}{l}\text { The International Agency for Research on Cancer evaluates the } \\
\text { carcinogenic risk of chemical substances to humans and group } \\
\text { substances according to the level of proof on human and animal } \\
\text { carcinogenity (IARC, 2004). According to Hofstetter (1998) the } \\
\text { egalitarian perspective is risk adverse and includes all substances } \\
\text { with insufficient evidence of carcinogenity (IARC categories } 1 \text {, } \\
\text { 2A, 2B and 3), the hierarchist perspective reflects a balance } \\
\text { between evidence and probability and includes substances with }\end{array}$ & $\begin{array}{l}\text { IARC } \\
\text { classification: } \\
1\end{array}$ & $\begin{array}{l}\text { IARC } \\
\text { classificatio } \\
\text { n: } 1,2 \mathrm{~A} \text { and } \\
2 \mathrm{~B}\end{array}$ & $\begin{array}{l}\text { All } \\
\text { substances }\end{array}$ & $\mathrm{U}$ \\
\hline
\end{tabular}




\begin{tabular}{|c|c|c|c|c|c|c|}
\hline & & $\begin{array}{l}\text { sufficient evidence (IARC categories } 1,2 \mathrm{~A} \text { and } 2 \mathrm{~B} \text { ), and the } \\
\text { individualist perspective includes substances with strong } \\
\text { evidence only (IARC category } 1 \text { ). We follow this vision, except } \\
\text { for the egalitarian perspective where all substances with a TD50 } \\
\text { are included. }\end{array}$ & & & & \\
\hline & & $\begin{array}{l}\text { The type and level of response for noncarcinogenic effects is } \\
\text { uncertain (Huijbregts et al., 2005) and therefore excluded from } \\
\text { the individualistic perspectives. }\end{array}$ & Excluded & Included & Included & $\mathrm{U}$ \\
\hline & 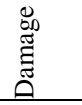 & $\begin{array}{l}\text { Generic value choices only (presented for all ICs at start of the } \\
\text { table). }\end{array}$ & I & I & / & I \\
\hline \multirow{4}{*}{ 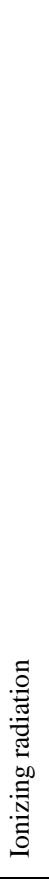 } & 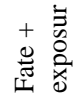 & $\begin{array}{l}\text { Generic value choices only (presented for all ICs at start of the } \\
\text { table). }\end{array}$ & I & I & I & I \\
\hline & \multirow[b]{2}{*}{ 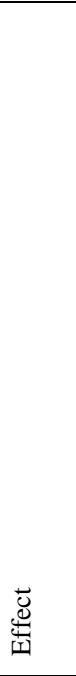 } & $\begin{array}{l}\text { The 'dose and dose-rate effectiveness factor' (DDREF) } \\
\text { describes the ratio between the risk increase per Man.Sv } \\
\text { observed at high doses and the assed risks at low doses. The } \\
\text { DDREF is found to be between } 2 \text { and } 10 \text {. A value of } 2 \text { is } \\
\text { recognized as being conservative and therefore assumed for the } \\
\text { egalitarian perspective (ICRP, 1990). A DDREF factor of } 6 \text { is } \\
\text { preliminary proposed for the hierarchist perspective and value of } \\
10 \text { for the individualist perspective. }\end{array}$ & 10 & 6 & 2 & $\mathrm{U}$ \\
\hline & & $\begin{array}{l}\text { Based on the amount of knowledge not all effects are included in } \\
\text { the different perspectives. Bladder, colon, ovary, skin, liver, } \\
\text { oesophagus and stomach cancer are possibly or probably } \\
\text { connected with ionizing radiation and thus only included in the } \\
\text { egalitarian and hierarchist perspectives. For bone surface and } \\
\text { remainder cancer no information about the level of proof is } \\
\text { available and therefore are only included in the egalitarian } \\
\text { perspective. Thyroid, bone marrow, lung and breast cancer are } \\
\text { definitely associated to ionizing radiation and thus considered } \\
\text { for all perspectives (Frischknecht et al., 2000). }\end{array}$ & $\begin{array}{l}\text { Thyroid, bone } \\
\text { marrow, lung } \\
\text { and breast } \\
\text { cancer }\end{array}$ & $\begin{array}{l}\text { Thyroid, } \\
\text { bone } \\
\text { marrow, } \\
\text { lung, breast, } \\
\text { bladder, } \\
\text { colon, ovary, } \\
\text { skin, liver } \\
\text { oesophagus, } \\
\text { and stomach } \\
\text { cancer }\end{array}$ & $\begin{array}{l}\text { Thyroid, } \\
\text { bone } \\
\text { marrow, } \\
\text { lung, breast, } \\
\text { bladder, } \\
\text { colon, ovary, } \\
\text { skin, liver, } \\
\text { oesophagus, } \\
\text { stomach, } \\
\text { bone } \\
\text { surface, and } \\
\text { remaining } \\
\text { cancer }\end{array}$ & $\mathrm{U}$ \\
\hline & 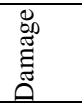 & $\begin{array}{l}\text { Generic value choices only (presented for all ICs at start of the } \\
\text { table). }\end{array}$ & I & I & / & I \\
\hline \multirow{4}{*}{ 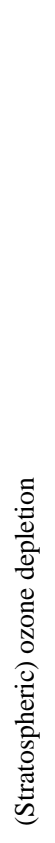 } & 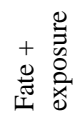 & $\begin{array}{l}\text { Generic value choices only (presented for all ICs at start of the } \\
\text { table). }\end{array}$ & I & I & I & I \\
\hline & \multirow[b]{2}{*}{ 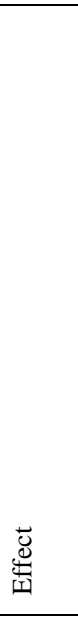 } & $\begin{array}{l}\text { Not all effects of ozone have the same level of evidence. Effects } \\
\text { of skin cancer (malignant malenoma, basel cell carcinoma and } \\
\text { squamous cell carcinoma) solar keratoses and photoaging are } \\
\text { certain and can be included for all perspectives. The evidence of } \\
\text { increased incidence of cataract, pterygium herpes and sunburn } \\
\text { due to increased UV-B radiation is weak (Lucas et al., 2008) and } \\
\text { therefore included for the egalitarian perspective only. }\end{array}$ & $\begin{array}{l}\text { Malignant } \\
\text { malenoma, } \\
\text { basel cell } \\
\text { carcinoma, } \\
\text { squamous cell } \\
\text { carcinoma, } \\
\text { solar keratoses } \\
\text { and photoaging }\end{array}$ & $\begin{array}{l}\text { Malignant } \\
\text { malenoma, } \\
\text { basel cell } \\
\text { carcinoma, } \\
\text { squamous } \\
\text { cell } \\
\text { carcinoma, } \\
\text { solar } \\
\text { keratoses } \\
\text { and } \\
\text { photoaging }\end{array}$ & $\begin{array}{l}\text { Malignant } \\
\text { malenoma, } \\
\text { basel cell } \\
\text { carcinoma, } \\
\text { squamous } \\
\text { cell } \\
\text { carcinoma, } \\
\text { solar } \\
\text { keratoses, } \\
\text { photo aging, } \\
\text { cataract, } \\
\text { herpes, } \\
\text { sunburn and } \\
\text { pterygium }\end{array}$ & $\mathrm{U}^{\mathrm{b}}$ \\
\hline & & $\begin{array}{l}\text { The inclusion of positive effects, like vitamin D efficiency is } \\
\text { considered a value choice on the level of concern (Jager et al., } \\
\text { 1997) and only included for the individualist perspective as they } \\
\text { consider nature as being stable with assured recovery } \\
\text { (Hofstetter, 1998). }\end{array}$ & Included & Excluded & Excluded & $C$ \\
\hline & $\begin{array}{l}\mathscr{\Xi} \\
\stackrel{\Delta}{\Xi} \\
\tilde{\Xi} \\
\end{array}$ & $\begin{array}{l}\text { Generic value choices only (presented for all ICs at start of the } \\
\text { table). }\end{array}$ & I & I & / & I \\
\hline
\end{tabular}




\begin{tabular}{|c|c|c|c|c|c|c|}
\hline \multirow{3}{*}{ 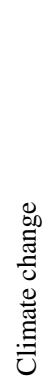 } & 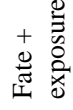 & $\begin{array}{l}\text { Generic value choices only (presented for all ICs at start of the } \\
\text { table). }\end{array}$ & I & I & I & / \\
\hline & 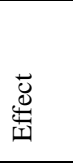 & $\begin{array}{l}\text { The inclusion of positive effects from ozone depletion } \\
\text { substances is a value choice on the level of concern (Jager et al., } \\
\text { 1997) and only included for the individualist perspective as they } \\
\text { consider nature as being stable with assured recovery } \\
\text { (Hofstetter, 1998). }\end{array}$ & Included & Excluded & Excluded & C \\
\hline & 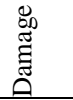 & $\begin{array}{l}\text { Generic value choices only (presented for all ICs at start of the } \\
\text { table). }\end{array}$ & I & I & I & I \\
\hline
\end{tabular}

Note: The value choices printed in grey italic are not implemented in our characterization factors (CFs). $\mathrm{C}=$ value choice on the level of concern;

$\mathrm{U}=$ value choice on the level of uncertainty; $\mathrm{m}^{3} / \mathrm{yr}=$ cubic meter per year.

${ }^{a}$ Value choice only considered within the CFs of the impact category climate change.

${ }^{\mathrm{b}}$ Only the effects of skin cancer and cataract are included in the CFs.

\section{Time horizon}

For the impact categories human toxicity, ionizing radiation, stratospheric ozone depletion and climate change, time horizon specific calculations were required. For human toxicity, USES-LCA readily provides fate and exposure results for a 100 year and infinite time horizon Van Zelm et al. (2009). USES-LCA was adapted to calculate fate and exposure factors for a time horizon of 20 years as well. For ionizing radiation, time horizon-specific exposure factors of most radio-active substances were given by IAEA (1985) and Frischknecht et al. (2000). For a limited number of substances, exposure factors for a 20 years time horizon were derived by linear extrapolation between a 10 and 50 years time horizon (emitted to freshwater and marine water: I-129; emitted to air: C-14, I-229, C-137) or by using a 50 years time horizon as first approximation (emitted to freshwater: C-137; emitted to air: H-3; emitted marine water: Am-241, C-14, Cs-137, H3, Ru-106) (see Supporting Information S2). For stratospheric ozone depletion, characterization factors (CFs) were provided for an infinite time horizon only (Hayashi et al., 2006). Fate and exposure factors for the time horizons of 20 years and 100 years were derived by calculating the fraction of exposure via:

$F_{t}=1-e^{(-t-t s) * k}$ 
where $F_{t}$ is the fraction of exposure for time horizon $t, k$ the degradation rate of the substance in the atmosphere (year ${ }^{-1}$ ) and ts the time needed for the substance to reach the atmosphere (year). A transport time (ts) of 3 years was assumed (WMO, 1995). For climate change, the fate and exposure factors were readily available for all three time horizons considered (De Schryver et al., 2009).

\section{Disability-adjusted life years}

Each perspective has different visions on age weighting and discount rate, both affecting the disability-adjusted life year (DALY) values. For the individualist perspective, $5 \%$ discount rate and age weighting was assumed, presented as [0.05,1], for the hierarchist perspective $3 \%$ discount rate and no age weighting was assumed, presented as $[0.03,0]$, and for the egalitarian perspective no age weighting or discounting was assumed, presented as $[0,0]$.

The DALY values were calculated by implementing the necessary information into the world health organization burden of disease template (WHO, 2008a). For the impact categories human toxicity, climate change and ionizing radiation the age specific duration values, incidence rates, age at onset and number of deaths were taken from the report Human Health Statistics 1990 (Murray and Lopez, 1996b), and the disability weights were derived from the Global Burden of Disease 1990 (Murray and Lopez, 1996a). For climate change (De Schryver et al., 2009) the DALYs [0.03,1] of the optimistic 2030 scenario (Mathers and Loncar, 2006) were converted to DALY with $5 \%$ discount rate and age weighting. Therefore, the ratio of the DALY $[0.03,1]$ and DALY [0.05,1] for year 1990 per disease and world region was used as scaling factor (Murray and Lopez, 1996a, Murray and Lopez, 1996b). The CFs for ozone depletion (Hayashi et al., 2006) and water scarcity (Pfister et al. 2009) were adapted to the corresponding age weighting 
and discount rate by applying the ratio of the required DALY and the original DALY. For the impact categories particulate matter and photochemical ozone formation the age specific population numbers and number of deaths were taken from the Global Burden of Disease 2004 update (WHO, 2008b). Age specific duration times, disability weights and incidence rates were derived from van Zelm et al. (2008). For each impact category the DALYs per incidence case are presented in table S-2. For climate change, the DALYs per degree Celsius increase are presented in table $\mathrm{S}-3$. 
Table S1-2. The disability-adjusted life year per incidence case calculated for the different impact categories, following three different perspectives.

\begin{tabular}{|c|c|c|c|}
\hline & Individualist & Hierarchist & Egalitarian \\
\hline Impact category & {$[0.05,1]$} & {$[\mathbf{0 . 0 3 , 0 ]}$} & {$[0,0]$} \\
\hline \multicolumn{4}{|l|}{ Water scarcity } \\
\hline Nutritional deficiencies & $1.5 \mathrm{E}+1$ & $2.0 \mathrm{E}+1$ & $4.1 \mathrm{E}+1$ \\
\hline \multicolumn{4}{|l|}{ Ozone formation } \\
\hline Acute mortality & $8.8 \mathrm{E}-2$ & $1.3 \mathrm{E}-1$ & $2.5 \mathrm{E}-1$ \\
\hline Asthma attacks & $3.1 E-4$ & $2.7 E-4$ & $2.7 \mathrm{E}-4$ \\
\hline Minor restricted activity days & $1.0 E-4$ & $8.5 E-5$ & $8.5 \mathrm{E}-5$ \\
\hline Respiratory hospital admissions & $1.2 E-2$ & $1.1 E-2$ & $1.1 \mathrm{E}-2$ \\
\hline Symptom days & $1.6 E-4$ & $1.3 E-4$ & $1.4 \mathrm{E}-4$ \\
\hline ERV for asthma & $9.4 E-4$ & $8.2 E-4$ & $8.2 \mathrm{E}-4$ \\
\hline \multicolumn{4}{|l|}{ Particulate matter } \\
\hline Chronic mortality & $3.5 \mathrm{E}+0$ & $5.2 \mathrm{E}+0$ & $1.0 \mathrm{E}+1$ \\
\hline Acute respiratory morbidity & $3.0 \mathrm{E}-2$ & $2.6 \mathrm{E}-2$ & $2.6 \mathrm{E}-2$ \\
\hline Acute cardiovascular morbidity & $3.3 \mathrm{E}-2$ & $2.8 \mathrm{E}-2$ & $2.8 \mathrm{E}-2$ \\
\hline \multicolumn{4}{|l|}{ Human toxicity } \\
\hline Cancer average & $4.8 \mathrm{E}+0$ & $7.9 \mathrm{E}+0$ & $1.1 \mathrm{E}+1$ \\
\hline Noncancer average & $1.4 E+0$ & $1.9 \mathrm{E}+0$ & $2.7 \mathrm{E}+0$ \\
\hline \multicolumn{4}{|l|}{ Ionizing radiation } \\
\hline Thyroid cancer & $4.8 \mathrm{E}+0$ & $7.9 \mathrm{E}+$ & $1.1 \mathrm{E}+1$ \\
\hline Bone marrow & $5.7 \mathrm{E}+0$ & $8.4 \mathrm{E}+0$ & $1.4 \mathrm{E}+1$ \\
\hline Lung cancer & $6.8 \mathrm{E}+0$ & $1.2 \mathrm{E}+01$ & $1.6 \mathrm{E}+1$ \\
\hline Breast cancer & $3.2 \mathrm{E}+0$ & $5.1 \mathrm{E}+0$ & $7.6 \mathrm{E}+0$ \\
\hline Bladder cancer & $2.1 E+0$ & $3.8 \mathrm{E}+0$ & $5.0 \mathrm{E}+0$ \\
\hline Colon cancer & $3.8 E+0$ & $6.5 \mathrm{E}+0$ & $8.8 \mathrm{E}+0$ \\
\hline Ovary cancer & $5.5 E+O$ & $8.6 \mathrm{E}+0$ & $1.3 \mathrm{E}+1$ \\
\hline Skin cancer & $2.7 E+O$ & $4.3 \mathrm{E}+0$ & $6.3 \mathrm{E}+0$ \\
\hline Liver cancer & $9.7 E+0$ & $1.5 \mathrm{E}+1$ & $2.2 \mathrm{E}+1$ \\
\hline Oesophagus cancer & $7.5 E+0$ & $1.3 \mathrm{E}+1$ & $1.8 \mathrm{E}+1$ \\
\hline Stomach cancer & $5.8 E+0$ & $9.9 \mathrm{E}+0$ & $1.4 \mathrm{E}+1$ \\
\hline Bone surface & $4.8 E+0$ & $7.9 E+0$ & $1.1 \mathrm{E}+1$ \\
\hline Remainder & $4.8 E+0$ & $7.9 E+0$ & $1.1 \mathrm{E}+1$ \\
\hline Hereditary $^{\mathrm{a}}$ & $1.4 \mathrm{E}+1$ & $2.1 \mathrm{E}+1$ & $5.7 \mathrm{E}+1$ \\
\hline \multicolumn{4}{|l|}{ Ozone depletion } \\
\hline Melanoma and other skin cancer & $2.7 \mathrm{E}+0$ & $4.3 \mathrm{E}+0$ & $6.3 \mathrm{E}+0$ \\
\hline Cataract & $8.2 E-1$ & $1.0 E+0$ & $1.1 \mathrm{E}+0$ \\
\hline
\end{tabular}

Note: The figures printed in grey italic are not included for the corresponding perspective. $[0.05,1]=5 \%$ discount rate and age weighting; $[0.03,0]=3 \%$ discount rate and no age weighting; $[0,0]=$ no age weighting or discounting; ERV= emergency room visits.

${ }^{a}$ No future generation discounting is considered. 
Table S1-3. The disability-adjusted life year per degree Celsius increase for climate change (based on expected DALYs for the year 2030), following three different perspectives.

\begin{tabular}{|c|c|c|c|}
\hline & Individualist & Hierarchist & Egalitarian \\
\hline Impact category & {$[0.05,1]$} & {$[0.03,0]$} & {$[0,0]$} \\
\hline \multicolumn{4}{|l|}{ Climate change } \\
\hline Cardiovascular & $0.0 \mathrm{E}+0$ & $2.5 \mathrm{E}+5$ & $7.6 \mathrm{E}+5$ \\
\hline Diarrhoe & $4.8 \mathrm{E}+5$ & $1.2 \mathrm{E}+6$ & $4.5 \mathrm{E}+6$ \\
\hline Malnutrition & $0.0 \mathrm{E}+0$ & $3.6 \mathrm{E}+6$ & $2.0 \mathrm{E}+7$ \\
\hline Malaria & $4.1 \mathrm{E}+5$ & $1.2 \mathrm{E}+6$ & $4.5 \mathrm{E}+6$ \\
\hline Nat disasters ${ }^{\mathrm{a}}$ & $2.0 \mathrm{E}+2$ & $-1.3 \mathrm{E}+5$ & $-5.0 \mathrm{E}+5$ \\
\hline
\end{tabular}

\section{Results}

\section{Characterization factors of water scarcity}

For water use CFs were calculated on a country level. This is defined as regionalized impact assessment. Data on annual freshwater availability and water withdrawals were derived from the Watergap2 global model (Alcamo et al., 2003), while data on flow regulation were derived from Pfister et al. (2009). Geographic information system allows data processing on different spatial resolutions (ESRI, 2004) and was used to calculate the new water scarcity index (WSI) per country (see Supporting Information S2). Using the ratios of our calculations on the water requirement, the WSI and the damage factor of Pfister et al. (2009), the CFs from Pfister et al. (2009) were extrapolated for the three perspectives. CFs were calculated for 165 countries and are presented in Supporting Information S2.

\section{Characterization factors of all impact categories}

The CFs for each substance and each impact category can be found in Supporting Information S2.

\section{Global damage}


The link between inventory data and impact assessment CFs is not always achieved. All carbon containing substances degrade partly to carbon dioxide. For example, over 90\% of atmospheric methane degrades to carbon dioxide while the rest is absorbed by micro-organisms in the soil (Badr et al., 1992). In this analysis, no degradation products are included in the inventory dataset or the calculated CFs. For fossil emissions this results in a slight underestimation of the calculated global damage. For biogenic emissions (emissions from the product originally derived from absorbed carbon dioxide from air; such as biogenic methane released by plant products) both the uptake of carbon dioxide as the degradation of the emitted carbon containing substance is excluded, what compensates each other and results in an relative zero effect. The global inventory dataset presents 'methane' emissions as a combination of biogenic and fossil methane. We applied the $\mathrm{CF}$ of fossil methane what generates a slight underestimation of the damage. 
Table S1-4. Percentage damage contribution (\%) of substances that contribute for more than 5\% to the global damage of emissions and water consumption of the year 2000.

\begin{tabular}{|c|c|c|c|c|c|c|c|c|c|}
\hline \multirow{2}{*}{ IC } & \multirow{2}{*}{ Country } & \multirow{2}{*}{\multicolumn{2}{|c|}{\begin{tabular}{|l} 
Water \\
consumption \\
$\left(\mathbf{m}^{3} /\right.$ capita)
\end{tabular}}} & \multicolumn{3}{|c|}{ CFs (DALY/m³) } & \multicolumn{3}{|c|}{ Global damage result (\% contribution) } \\
\hline & & & & Individualist & Hierarchist & Egalitarian & Individualist & Hierarchist & Egalitarian \\
\hline \multirow{7}{*}{ 绨 } & India & \multicolumn{2}{|c|}{$5.1 \mathrm{E}+02$} & $9.5 \mathrm{E}-7$ & $2.0 \mathrm{E}-6$ & $4.7 \mathrm{E}-6$ & 59.0 & 59.8 & 59.8 \\
\hline & Pakistan & \multicolumn{2}{|c|}{$6.8 \mathrm{E}+02$} & $9.9 \mathrm{E}-7$ & $1.9 \mathrm{E}-6$ & $4.5 \mathrm{E}-6$ & 11.1 & 10.6 & 10.6 \\
\hline & China & \multicolumn{2}{|c|}{$2.4 \mathrm{E}+02$} & $1.4 \mathrm{E}-7$ & $2.7 \mathrm{E}-7$ & $6.5 \mathrm{E}-7$ & 5.2 & 4.9 & 4.9 \\
\hline & Afganistan & \multicolumn{2}{|l|}{$2.0 \mathrm{E}+03$} & $7.4 \mathrm{E}-7$ & $1.4 \mathrm{E}-6$ & $3.4 \mathrm{E}-6$ & 3.5 & 3.3 & 3.3 \\
\hline & All other countries & & & & & & 21.3 & 21.4 & 21.4 \\
\hline & \multicolumn{6}{|c|}{ Total damage for this impact category (in DALY/capita) } & $1.4 E-4$ & $2.8 E-4$ & $6.7 E-4$ \\
\hline & Substance & $\begin{array}{l}\text { Emiss. } \\
\text { Comp. }\end{array}$ & $\begin{array}{l}\text { Emission } \\
\text { (kg/capita) }\end{array}$ & \multicolumn{3}{|c|}{ CFs (DALY/kg or DALY/kBq) } & \multicolumn{3}{|c|}{ Global damage result (\% contribution) } \\
\hline \multirow{5}{*}{ 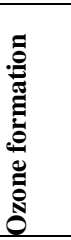 } & $\begin{array}{l}\text { Non-methane volatile } \\
\text { organic compounds } \\
\text { (NMVOC), unspecified }\end{array}$ & Air & $2.7 \mathrm{E}+1$ & $1.4 \mathrm{E}-8$ & $2.0 \mathrm{E}-8$ & $2.0 \mathrm{E}-7$ & 98.1 & 55.1 & 55.1 \\
\hline & Nitrogen oxides & Air & $1.9 \mathrm{E}+1$ & $-4.2 \mathrm{E}-8$ & $2.0 \mathrm{E}-8$ & $2.0 \mathrm{E}-7$ & $-210.0^{\mathrm{a}}$ & 38.3 & 38.3 \\
\hline & Sulfur dioxide & Air & $2.1 \mathrm{E}+1$ & $1.1 \mathrm{E}-9$ & $1.7 \mathrm{E}-9$ & $1.6 \mathrm{E}-8$ & 6.2 & 3.5 & 3.5 \\
\hline & Remaining substances & & & & & & 0.7 & 0.3 & 0.3 \\
\hline & \multicolumn{6}{|c|}{ Total damage for this impact category (in DALY/capita) } & $-3.8 E-7$ & $1.0 E-6$ & $1.0 E-5$ \\
\hline & Particulates, $<10 \mu \mathrm{m}$ & Air & $4.8 \mathrm{E}+$ & $9.2 \mathrm{E}-5$ & $1.4 \mathrm{E}-4$ & $2.6 \mathrm{E}-4$ & 100.0 & 53.2 & 34.3 \\
\hline & Sulfur dioxide & Air & $2.1 \mathrm{E}+1$ & - & $2.7 \mathrm{E}-5$ & $5.1 \mathrm{E}-5$ & - & 46.8 & 30.1 \\
\hline 苞 & Nitrogen oxides & Air & $1.9 \mathrm{E}+1$ & - & - & $5.7 \mathrm{E}-5$ & - & - & 30.0 \\
\hline$\frac{\pi}{3}$ & Ammonia & Air & $2.5 \mathrm{E}+$ & - & - & $8.2 \mathrm{E}-5$ & - & - & 5.7 \\
\hline 焉 & Remaining substances & & & & & & 0.0 & 0.0 & 0.0 \\
\hline Е & Total damage for this im & act categ & gory (in DALI & Y/capita) & & & $4.4 E-4$ & $1.2 E-3$ & $3.6 E-3$ \\
\hline & Benzene & Air & $2.4 \mathrm{E}+0$ & $3.5 \mathrm{E}-7$ & $8.4 \mathrm{E}-7$ & $1.1 \mathrm{E}-6$ & 40.9 & 3.9 & 0.5 \\
\hline & Formaldehyde & Air & $1.2 \mathrm{E}-2$ & $4.9 \mathrm{E}-5$ & $6.7 \mathrm{E}-5$ & $1.3 \mathrm{E}-4$ & 27.3 & 1.5 & 0.3 \\
\hline & Chromium & Air & $2.6 \mathrm{E}-4$ & $1.3 \mathrm{E}-3$ & $3.3 \mathrm{E}-3$ & $1.4 \mathrm{E}-7$ & 16.4 & 1.6 & 0.0 \\
\hline & Dioxins & Air & $3.0 \mathrm{E}-9$ & $5.5 \mathrm{E}+1$ & $8.6 \mathrm{E}+1$ & $1.3 \mathrm{E}+2$ & 8.0 & 0.5 & 0.1 \\
\hline & Nickel & Air & $5.7 \mathrm{E}-4$ & $2.2 \mathrm{E}-4$ & $4.0 \mathrm{E}-4$ & $6.4 \mathrm{E}-4$ & 6.0 & 0.4 & 0.1 \\
\hline & Mercury & Air & $4.9 \mathrm{E}-5$ & - & $4.2 \mathrm{E}-1$ & $9.5 \mathrm{E}-1$ & - & 39.2 & 8.5 \\
\hline & Chlorine & Water & $1.1 \mathrm{E}-2$ & - & $5.2 \mathrm{E}-5$ & $7.0 \mathrm{E}-5$ & - & 14.2 & 1.8 \\
\hline & Lead & Air & $1.5 \mathrm{E}-3$ & - & $4.8 \mathrm{E}-3$ & $9.6 \mathrm{E}-3$ & - & 13.4 & 2.5 \\
\hline & Arsenic & Air & $1.8 \mathrm{E}-4$ & $4.2 \mathrm{E}-6$ & $1.5 \mathrm{E}-2$ & $2.3 \mathrm{E}-1$ & 0.0 & 5.3 & 7.3 \\
\hline & Selenium & Air & $1.3 \mathrm{E}-4$ & - & $1.8 \mathrm{E}-3$ & $2.2 \mathrm{E}+0$ & - & 0.5 & 51.5 \\
\hline & Selenium & Water & $1.3 \mathrm{E}-4$ & - & $2.3 \mathrm{E}-3$ & $2.8 \mathrm{E}+0$ & - & 0.1 & 5.1 \\
\hline & Barium & Soil & $5.0 \mathrm{E}-4$ & - & $5.1 \mathrm{E}-5$ & $2.5 \mathrm{E}-2$ & - & 1.2 & 3.6 \\
\hline & Zinc & Soil & $3.3 \mathrm{E}-3$ & - & $2.0 \mathrm{E}-6$ & $1.3 \mathrm{E}-4$ & - & 1.6 & 2.3 \\
\hline & Lead & Soil & $1.5 \mathrm{E}-3$ & - & $9.2 \mathrm{E}-7$ & $6.8 \mathrm{E}-4$ & 0.0 & 13.4 & 2.3 \\
\hline & Barium & Air & $5.0 \mathrm{E}-4$ & - & $2.1 \mathrm{E}-4$ & $2.3 \mathrm{E}-2$ & - & 0.2 & 2.1 \\
\hline & Manganese & Water & $7.7 \mathrm{E}-4$ & - & $2.1 \mathrm{E}-4$ & $5.3 \mathrm{E}-3$ & - & 0.3 & 1.9 \\
\hline & Manganese & Air & $7.7 \mathrm{E}-4$ & - & $9.8 \mathrm{E}-4$ & $1.1 \mathrm{E}-2$ & - & 0.3 & 1.5 \\
\hline & Barium & Water & $5.0 \mathrm{E}-4$ & - & $1.3 \mathrm{E}-4$ & $2.7 \mathrm{E}-2$ & - & 0.3 & 1.4 \\
\hline 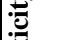 & Arsenic & Soil & $1.8 \mathrm{E}-4$ & $3.0 \mathrm{E}-8$ & $8.3 \mathrm{E}-5$ & $1.4 \mathrm{E}-1$ & 0.0 & 0.2 & 1.2 \\
\hline ês & Cadmium & Air & $6.8 \mathrm{E}-5$ & $2.0 \mathrm{E}-4$ & $1.9 \mathrm{E}-2$ & $9.1 \mathrm{E}-2$ & 0.7 & 0.2 & 1.1 \\
\hline$\ddot{\Xi}$ & Vanadium & Air & $6.0 \mathrm{E}-4$ & - & $1.1 \mathrm{E}-3$ & $8.4 \mathrm{E}-3$ & - & 0.2 & 0.9 \\
\hline 营 & Remaining substances & & & & & & 0.6 & 1.7 & 4.1 \\
\hline$\Xi$ & Total damage for this im & act categ & gory (in DALI & Y/capita) & & & $2.1 E-6$ & $1.2 \mathrm{E}-2$ & $4.9 \mathrm{E}-5$ \\
\hline & Cesium-137 & Water & $3.9 \mathrm{E}+1$ & $2.4 \mathrm{E}-8$ & $2.4 \mathrm{E}-8$ & $2.4 \mathrm{E}-8$ & 78.9 & 71.8 & 19.1 \\
\hline & Carbon-14 & Air & $9.5 \mathrm{E}+1$ & $1.6 \mathrm{E}-9$ & $1.6 \mathrm{E}-9$ & $1.6 \mathrm{E}-9$ & 12.9 & 19.9 & 59.4 \\
\hline .0 & Cobalt-60 & Water & $6.2 \mathrm{E}+$ & $7.0 \mathrm{E}-9$ & 7.0E-9 & $7.0 \mathrm{E}-9$ & 3.6 & 3.0 & 0.8 \\
\hline 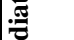 & Cesium-134 & Water & $1.2 \mathrm{E}+$ & $2.3 \mathrm{E}-8$ & $2.3 \mathrm{E}-8$ & $2.3 \mathrm{E}-8$ & 2.2 & 1.9 & 0.5 \\
\hline I & Technetium-99 & Water & $2.2 \mathrm{E}+2$ & $2.0 \mathrm{E}-11$ & $2.0 \mathrm{E}-11$ & $2.0 \mathrm{E}-11$ & 0.4 & 1.3 & 0.3 \\
\hline 00 & Iodine-129 & Water & $2.4 \mathrm{E}+$ & $6.7 \mathrm{E}-10$ & $6.7 \mathrm{E}-10$ & $6.7 \mathrm{E}-10$ & 0.1 & 0.1 & 18.1 \\
\hline - & Remaining substances & & & & & & 1.9 & 2.1 & 1.8 \\
\hline పق & Total damage for this im & act categ & gory (in DALY & Y/capita) & & & $1.2 E-6$ & $3.9 E-6$ & $2.8 E-5$ \\
\hline & CFC-12 & Air & $1.7 \mathrm{E}-2$ & $4.1 \mathrm{E}-5$ & $2.6 \mathrm{E}-4$ & $1.4 \mathrm{E}-3$ & 25.4 & 41.5 & 50.5 \\
\hline & CFC-11 & Air & $6.6 \mathrm{E}-3$ & $7.9 \mathrm{E}-5$ & $3.5 \mathrm{E}-4$ & $1.3 \mathrm{E}-3$ & 19.6 & 22.6 & 19.4 \\
\hline a & HCFC-141b & Air & $2.7 \mathrm{E}-2$ & $1.9 \mathrm{E}-5$ & $3.6 \mathrm{E}-5$ & $1.2 \mathrm{E}-4$ & 19.0 & 9.3 & 7.1 \\
\hline 象 & HCFC-22 & Air & $4.9 \mathrm{E}-2$ & $7.7 \mathrm{E}-6$ & $1.6 \mathrm{E}-5$ & $5.4 \mathrm{E}-5$ & 14.0 & 7.6 & 5.8 \\
\hline$\frac{\pi}{2}$ & Halon 1211 & Air & $7.9 \mathrm{E}-4$ & $4.1 \mathrm{E}-4$ & $1.0 \mathrm{E}-3$ & $3.4 \mathrm{E}-3$ & 12.2 & 7.7 & 5.8 \\
\hline 幽 & Halon 1301 & Air & $1.5 \mathrm{E}-4$ & $8.5 \mathrm{E}-4$ & $4.6 \mathrm{E}-3$ & $2.0 \mathrm{E}-2$ & 4.8 & 6.7 & 6.5 \\
\hline 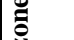 & Remaining substances & & & & & & 5.0 & & 5.0 \\
\hline 政 & Total damage for this im & act categ & gory (in DALY & Y/capita) & & & $2.7 E-6$ & $1.0 E-5$ & $4.6 E-5$ \\
\hline
\end{tabular}




\begin{tabular}{|c|c|c|c|c|c|c|c|c|c|}
\hline \multirow{6}{*}{ 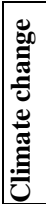 } & Carbon dioxide, fossil & Air & $4.7 \mathrm{E}+3$ & $7.4 \mathrm{E}-9$ & $2.6 \mathrm{E}-7$ & $1.8 \mathrm{E}-5$ & 47.7 & 65.3 & 92.7 \\
\hline & Methane $^{\mathrm{b}}$ & Air & $4.9 \mathrm{E}+1$ & $6.2 \mathrm{E}-7$ & $7.4 \mathrm{E}-6$ & $5.0 \mathrm{E}-5$ & 41.7 & 19.9 & 2.8 \\
\hline & Dinitrogen monoxide & Air & $1.9 \mathrm{E}+$ & $2.4 \mathrm{E}-6$ & $8.3 \mathrm{E}-5$ & $9.6 \mathrm{E}-4$ & 6.1 & 8.6 & 2.0 \\
\hline & HCFC-22 & Air & 4.9E-2 & $3.4 \mathrm{E}-5$ & $5.0 \mathrm{E}-4$ & $3.4 \mathrm{E}-3$ & 2.3 & 1.4 & 0.2 \\
\hline & Remaining substances & & & & & & 2.2 & 4.8 & 2.3 \\
\hline & \multicolumn{6}{|c|}{ Total damage for this impact category (in DALY/capita) } & $7.3 E-5$ & $1.8 E-3$ & $8.8 E-2$ \\
\hline
\end{tabular}

Note: For water scarcity, the four most contributing countries are presented. Global emissions (in $\mathrm{kg}$ or $\mathrm{kBq}$ ) and water consumption data per capita $\left(\mathrm{in}^{3}\right.$ ) is presented, together with the corresponding characterization factors (CFs in DALY $/ \mathrm{m}^{3}, \mathrm{DALY} / \mathrm{kg}$ or DALY $\left./ \mathrm{kBq}\right)$. Emiss. Comp= the compartment of emissions. $\mathrm{m}^{3}=$ cubic meter; $\mathrm{kg}=$ kilogram; $\mathrm{kBq}=$ kilobecquerel.

${ }^{a}$ For the individualist perspective positive effects from nitrogen oxides are included and therefore the CF turns negative. This results in a negative damage for the emission of nitrogen oxides and a total negative damage for ozone formation $(-100 \%)$.

${ }^{b}$ Sum of methane from biogenic and fossil origin. We applied the CF of fossil methane, generating therefore a slight underestimation of the damage.

Characterization factors for water consumption and 1239 substances, covering seven human health impact categories, can be found in the Supporting Information S2 (a separate excel document). For each impact category, the new recalculated CFs are presented together with the original CFs (defined as "original CFs"). For human toxicity the original CFs are not presented, as the figures directly derive from the model USES-LCA. 


\section{References}

Alcamo, J., P. Döll, T. Henrichs, F. Kaspar, B. Lehner, T. Rösch and S. Siebert. 2003. Development and Testing of the WaterGAP 2 Global Model of Water Use and Availability. Hydrological Science 48(3): 317-337.

Anderson, H.R., R.W. Atkinson, J.L. Peacock, L. Marston and K. Konstantinou. 2004. Metaanalysis of time-series studies and panel studies of Particulate Matter (PM) and Ozone (O3). Report of a WHO task group. London, World Health Organization.

Badr, O., S.D. Probert and P.W. O'Callaghan. 1992. Sinks for atmospheric methane. Applied Energy 41(2): 137-147.

De Schryver, A.M., K.W. Brakkee, M.J. Goedkoop and M.A.J. Huijbregts. 2009. Characterization Factors for Global Warming in Life Cycle Assessment based on Damages to Humans and Ecosystems. Environmental Science and Technology 43(6): 1689-1695.

ESRI. 2004. ArcGIS software (geographical information systems): Arcmap 9.2 (Licence Arcview). California, Environmental Systems Research Institute.

Frischknecht, R., A. Braunschweig, P. Hofstetter and P. Suter. 2000. Human health damages due to ionising radiation in life cycle impact assessment. Environmental Impact Assessment Review 20(2): 159-189.

Gold, M., J. Siegel, L. Russell and M. Weinstein. 1996. Cost effectiveness in health and medicine, New York, Oxford University Press.

Hayashi, K., A. Nakagawa, N. Itsubo and A. Inaba. 2006. Expanded Damage Function of Stratospheric Ozone Depletion to Cover Major Endpoints Regarding Life Cycle Impact Assessment. International Journal of Life Cycle Assessment 11:150-161.

Hendriks, A., A. van der Linde, C. Cornelissen and D. Sijm. 2001. The power of size: I. Rate constants and equilibrium ratios for accumulation of organic substances. Environmental Toxicology and Chemistry 20: 1399-1420.

Hofstetter, P. (Ed.) 1998. Perspectives In Life Cycle Impact Assessment. A structured approach to combine models of the technosphere, ecosphere and valuesphere Dordrecht, Kluwer Academic Publishers.

Huijbregts, M.A.J., L. Rombouts, A. Ragas and D. van de Meent. 2005. Human-toxicological effect and damage factors of carcinogenic and noncarcinogenic chemicals for life cycle impact assessment. Integrated Environmental Assessment and Management 1(3): 181244.

IAEA. 1985. The Radiological impact of Radionuclides Dispersed on a Regional and Global Scale: Methods for Assessment and their Application. Technical reports series no 250. Vienna, IAEA.

IARC. http://www.inchem.org/pages/iarc.html. Accessed 23 June 2011

ICRP. 1990. Recommendations of the International Commission on Radiological Protection. Publication 60. Oxford, ICRP. 
IPCC. 2000. Emission Scenarios: Special report of Working Group III. Summary for policy makers. Geneva, IPCC.

Jager, W., M.B.A. Van Asselt, J. Rotmans, C.A.J. Vlek and P. Costerman Boodt. 1997. Consumer Behaviour: A Modelling Perspective in the Context of Integrated Assessment of Global Change. Globo Report Series Bilthoven, RIVM.

Janssen, M. and J. Rotmans. 1995. Allocation of fossil CO2 emission rights quantifying cultural perspectives. Ecological Economics 13(1): 65-79.

Lucas, R.M., A.J. McMichael, B.K. Armstrong and W.T. Smith. 2008. Estimating the global disease burden due to ultraviolet radiation exposure. International Journal of Epidemiology 37(3): 14

Mathers, C.D. and D. Loncar. 2006. Projections of Global Mortality and Burden of Disease from 2002 to 2030. PLoS Medicine 3(11): 2011-2030.

Murray, C. and A. Lopez. 1996a. The Global Burden of Disease: A comprehensive assessment of mortality and disability from diseases, injuries, and risk factors in 1990 and projected to 2020, Boston, WHO.

Murray, C. and A. Lopez. 1996b. Global health statistics: A compendium of incidence, prevalence, and mortality estimates for over 200 conditions, Boston, WHO.

Murray, C. and A. Lopez. 1996c. Rethinking DALYs. The Global Burden of Disease. Boston, WHO.

Murray, C. and A. Lopez. 1997. Alternative projections of mortality and disability by cause 1990-2020: Global Burden of Disease Study. The Lancet 349(9064):1498-1504.

Pfister, S., A. Koehler and S. Hellweg. 2009. Assessing the Environmental Impacts of Freshwater Consumption in LCA. Environmental Science \& Technology 43(11): 4098-4104.

Pope, C.A., III, M. Ezzati and D.W. Dockery. 2009. Fine-Particulate Air Pollution and Life Expectancy in the United States. New England Journal of Medicine 360(4): 376-386.

Reiss, R., E.L. Anderson, C.E. Cross, G. Hidy, D. Hoel, R. McClellan and S. Moolgavkar. 2007. Evidence of Health Impacts of Sulfate-and Nitrate-Containing Particles in Ambient Air. Inhalation Toxicology: International Forum for Respiratory Research 19(5): 419 - 449.

Thompson, M., R. Ellis and A. Wildavsky. 1990. Cultural Theory, Boulder, Westview Press.

Torfs, R., F. Hurley, B. Miller and A. Rabl. 2007. A set of concentration-response functions. NEEDS project. Stuttgart, Universität Stuttgart.

USEPA. 2009. Green book Nonattainment areas for criteria pollutions. IN AGENCY, U. E. P. (Ed.). United States Environmental Protection Agency.

van Asselt, M., A. Beusen and H. Hilderink. 1996. Uncertainty in integrated assessment: A social scientific perspective. Environmental Modeling and Assessment 1(1): 71-90.

van Asselt, M. and J. Rotmans. 1996. Uncertainty in perspective. Global Environmental Change 6(2): 121-157.

Van Zelm, R., M.A.J. Huijbregts, H.A. Den Hollander, H.A. Van Jaarsveld, F.J. Sauter, J. Struijs, H.J. Van Wijnen and D. Van de Meent. 2008. European characterization factors for 
human health damage of PM10 and ozone in life cycle impact assessment. Atmospheric Environment 42: 441-453.

Van Zelm, R., M.A.J. Huijbregts and D. van de Meent. 2009. USES-LCA 2.0-a global nested multi-media fate, exposure, and effects model. International Journal of Life Cycle Assessment 14(3): 282-284.

Vonk, J. and J. Schouten. 2002. Daily emergency hospital admissions and air pollution in the Netherlands 1992-1999. Groningen, University of Groningen.

WHO. 2008a. Burden of Diseases reference DALYs: calculation template. Geneva, Switserland, World Health Organization.

WHO. 2008b. The global burden of disease: 2004 update. 1.Cost of illness. 2.World health statistics. 3.Mortality - trends. Geneva, World Health Organization.

WMO. 1995. Scientific Assessment of Ozone Depletion. WMO report, 37. Geneva, World Meteorological Organization. 